\title{
A Need Analysis in Academic Writing by Using Integrative-Based Approach: The Perspective of University Students
}

\author{
Helaluddin* \\ Faculty of Islamic Economic \& \\ Bussines \\ Islamic State University of Sultan \\ Maluna Hasanuddin Banten \\ Serang, Indonesia \\ helaluddin@uinbanten.ac.id
}

\author{
Hengki Wijaya \\ Faculty of Philosophy Science of \\ Theology \\ Sekolah Tinggi Filsafat Jaffray \\ Makassar \\ Makassar, Indonesia \\ hengkilily1988@gmail.com
}

\author{
Nurmadiah \\ Faculty of Islamic Education \\ (PAI) \\ East Indonesian University of \\ Makassar \\ Makassar, Indonesia \\ rnurmadiah@gmail.com
}

\author{
Susanna Vonny N. Rante \\ Faculty of Teacher Training \& \\ Education \\ Indonesian Christian University \\ of Toraja \\ Toraja, Indonesia \\ vonny@ukitoraja.ac.id
}

\author{
Harmelia Tulak \\ Faculty of Teacher Training \& Education \\ Indonesian Christian University of Toraja \\ Toraja, Indonesia \\ harmeliatulak@ukitoraja.ac.id
}

\begin{abstract}
This article discusses the needs and interests of the university students in Banten Indonesia for learning to write with an integrative approach as an initial stage in the development of academic writing textbooks. The participants in this study were 60 students in the first semester of the 2018/2019 academic year who took an Indonesian language course. It was found that students were familiar with writing activities. But the majority were limited to non-academic genres such as writing poetry, short stories, and writing personal blogs. Also, students have almost the same problems in academic writing, both from linguistic aspects, technical aspects, to issues of developing writing ideas. Another thing that was found in this study was the participation of lecturers who they expected in guiding and providing input during academic writing learning.
\end{abstract}

Keywords-need analysis, academic writing, integrative-based approach

\section{INTRODUCTION}

In learning the Indonesian language in higher education, one of the competencies to be achieved in writing competence. Writing activities can be regarded as activities that have a high degree of difficulty, even for experienced writers and beginner writers. Writing is the most challenging type of ability for both professional writers and students (Ezza, 2014).

Academic writing cannot be separated from academic literacy, which is one genre in the educational field (Åberg, Stahle, Engdahl, \& Knutes-Nyqvist, 2016). This type of writing activity has some stricter rules when compared to other genres. Various kinds of academic writing include notes (notes), reports, projects, essays, theses/dissertations, and papers (Bailey, 2011).

On the other hand, the definition of academic writing related by product-based approach. It is defined as an activity in producing material forms appropriately and based on the type determined at the sentence and discourse level (Tuyen, Osman, Ahmad, Dan, \& Kiumarsi, 2016). The ability of academic writing with a process-based approach (cognitiveoriented approach) is the ability to develop ideas and use writing processes such as revising or editing. The ability to write with a genre approach is the ability to write for a given purpose, a communication function, and to satisfy community discourse based on the structure and content of the discourse (Tuyen et al., 2016).

One of the weaknesses in writing learning so far is the mistakes of the instructors who only focus on language errors. Teachers tend to override various aspects that play an essential role in a writing activity. Many lecturers give low scores to students who experience many mistakes in grammar, even though these students have good ideas or ideas (Lap \& Truc, 2014). For this reason, writing activities must be interpreted as a combination of structural, grammatical, and lexical activities that cannot be separated from the context, purpose, and audience (Correa \& Echeverri, 2016). 
There are three types of approaches used in academic writing learning, namely a product-based approach, processbased approach, and genre-based approach. The three types of methods have their advantages and disadvantages. In minimizing these shortcomings, a plan was developed that combined these three types of procedures in academic writing learning. This combined approach is referred to as an integrative-based approach.

One of the earliest approaches to writing learning is a product-based approach. This approach emphasizes the final results in the form of writing. In this approach, students are directed to highlight the product (essay) rather than how the process of writing. The product-based approach views writing activity as centered on knowledge of language structure, and the development of writing is seen as the result of imitation (example) in the form of text provided by the teacher (Badger $\&$ White, 2000).

This approach is considered by some experts to have several weaknesses. Learning to write with a product approach will give some effect like 1) provide a little attention to students, 2) learners will lose motivation, and 3) give high pressure because the instructor is more focused on the accuracy of the language structure (Tangpermpoon, 2008).

Process approach can be interpreted as a method that emphasizes individual writers as creators of the original idea (Hashemnezhad \& Hashemnezhad, 2012). This approach can be seen as a writing activity that is not only concerned with grammar but also for finding meaning and beliefs (Tangpermpoon, 2008). According to Myles, a process-based or integrative approach to writing learning is to give students the opportunity to receive feedback and then give time to reflect and look for input as a re-form of plans, ideas, and languages (Pasand \& Haghi, 2013).

Furthermore, the teacher or lecturer in this approach functions as a facilitator who tries to arouse interest and ideas for his students. In this approach, the writing process takes precedence over the social context. That is, this approach is based more on linguistic abilities than on linguistic knowledge (Pramila, 2017).

The Genre-based approach is a concept of learning that affects the process of language education and teaching. On the other hand, this approach is an approach that emphasizes social and cultural dimensions in language and text (Amogne, 2013).

Furthermore, the genre is reflected as a social product and as an institutional context (Beck \& Jeffery, 2009). Using this approach model will be able to help students increase their awareness of the hardest parts of conveying autonomy through their writing activities. There are four stages in this approach, namely: 1) building the text, 2) modeling of the text, 3) joint construction of the text, and 4) independent development of the text.

The integrative-approach is a combination of process models and genre theories that are present as a realization of the limitations of both approaches for developing students' writing skills (Babalola \& Litinin, 2012). According to Badger and White, this approach focuses on knowledge of the language (product and genre approaches), context and purpose of writing (genre approach), and abilities needed in the use of language or process approaches (Pramila, 2017). There are six steps in learning to write using the process-genre method, namely preparation, modeling, and reinforcing, planning, joint constructing, independent constructing, and revising (Agesta $\&$ Cahyono, 2017).

In overcoming problems in learning to write, concrete steps are needed to overcome them. One of them is by developing academic writing textbooks using an integrative approach. The first step, the researcher collect initial information related to the needs of students and lecturers about academic writing learning in Indonesian Language Courses, which are called the needs analysis phase.

The term needs analysis or also known as need assessment is claimed to be an essential part of the curriculum planning process in language learning (Richards, 2011). This term was first introduced by Dr. Michael Ohilip West, a teacher and researcher in India in 1899-1973. He argued that it was important for children to learn languages and how they should learn words (Sultana, 2018).

Needs analysis is a process of gathering information related to the needs of students in learning (Brown, 2001). Needs analysis also interpreted as a gradual process in obtaining information about learners' needs, preferred choices, and problems identified by learners and subject developers, teachers, and graduates to adapt to learners' needs (Andi \& Arafah, 2017).

Hutchinson \& Waters state that needs analysis is the most prominent feature of language learning in designing more specific subjects (1987). Needs analysis is even stated as a starting point for creating courses and is an essential part of the curriculum and syllabus development (Eshtehardi, 2017).

There are several objectives to be achieved by the need analysis; 1) providing a mechanism for determining content input, design, and implementation of language programs through several people such as learners, teachers, administrators, and school workers; 2) identifying language needs in general and specifically aimed at developing general objectives, specific objectives, and content in language programs; 3) providing data that can be used to evaluate current programs (Richards, 1990).

\section{METHOD}

This research is a fundamental part of the research and development that uses a qualitative approach. Participants in this study were 60 first semester students in Banten Province, Indonesia. The participants were randomly selected from 4 campuses, namely: (1) 20 students from Islamic State University of Sultan Maulana Hasanuddin Banten, (2) 14 students from Serang Raya University, (3) 10 students from Institute of Banten Islamic Religion, and (4) 16 students from Banten Jaya University. 
The instrument in this study was developed to find information about learning academic writing with an integrative approach. The tools used in this study was a questionnaire. The questionnaire is a closed-ended question questionnaire containing 15 questions by providing several alternative answers. The questionnaire design used was a questionnaire developed from a framework of a needs analysis by Hutchinson \& Waters grouped into three main parts, namely: 1) student's language level, 2) student's language problem, and 3) student's language needs (Hutchinson \& Waters, 1987).

\section{RESULTS \& DISCUSSION}

As stated in the previous section, developing a textbook requires a variety of initial information collected through a questionnaire. The questionnaire was categorized into three sub-sections, namely student language level, student language problem, and student language needs.

\section{A. Students language level}

The first part of the questionnaire used in this study serves to collect information relating to the level of student writing competence. With this information, researchers can design academic writing textbooks by considering student competency levels to suit their needs. This section contains five questions by providing several answer choices. Sixty participants were given questions; $100 \%$ responded to each item.

The first and second questions in the early part are formulated to identify student preferences for learning academic writing. Related to the urgency (importance) of academic writing learning in Indonesian Language Courses, around $80 \%$ (48 students) participants stated strongly agree, and 20\% (12 students) answered they agree. On the second question, as many as 45 students $(75 \%)$ indicated that they were very fond of academic writing learning, 10 participants (17\%) expressed their likes, and 5 participants (8\%) stated neutrally.

TABLE 1. THE URGENCY OF ACADEMIC WRITING IN HIGHER EDUCATION

Academic writing learning in Indonesian Language courses at universities is significant benefits for students

\begin{tabular}{|c|c|}
\hline Strongly agree & $80 \%$ \\
\hline Agree & $20 \%$ \\
\hline Neutral & - \\
\hline Disagree & - \\
\hline Strongly disagree & - \\
\hline
\end{tabular}

TABLE 2. STUDENTS' FAVORITE TOWARDS WRITING LEARNING

\begin{tabular}{|c|c|}
\hline Do you like writing learning? \\
\hline Strongly agree & $75 \%$ \\
\hline Agree & $17 \%$ \\
\hline Neutral & $8 \%$ \\
\hline Disagree & - \\
\hline Strongly disagree & - \\
\hline
\end{tabular}

The third question is related to the use of students in participating in academic writing learning by providing four alternative answers. As many as 50\% of participants answered the purpose of academic writing needed in matters of work going forward. For further education, 25\% (chose this answer option while $15 \%$ of participants chose the answers to take the exam, and $10 \%$ answered for others.

TABLE 3. ACADEMIC WRITING LEARNING OBJECTIVES

\begin{tabular}{|c|c|}
\hline \multicolumn{2}{|c|}{ For what purpose are writing skills you need? } \\
\hline Further education & $25 \%$ \\
\hline Work & $50 \%$ \\
\hline $\begin{array}{c}\text { The Final examination of } \\
\text { the course }\end{array}$ & $15 \%$ \\
\hline Etc & $10 \%$ \\
\hline
\end{tabular}

The fourth question is used to identify student writing skills. From the results of the questionnaire analysis, it was found that $58 \%$ of students had written poetry, short stories, and novels while $23 \%$ claimed to have written a diary both through personal blogs and diary books. Furthermore, there were $13 \%$ of students who had written articles and essays, and $6 \%$ of students stated that they had written in other forms of writing. From these results, it can be concluded that the majority of students are accustomed to writing in the genre of non-scientific writing. That is, the majority of students have never written text in academic styles.

\section{TABLE 4. STUDENTS' WRITING}

\begin{tabular}{|c|c|}
\hline \multicolumn{2}{|c|}{ The form of writing that you have produced } \\
\hline Write diary/blog & $23 \%$ \\
\hline Writing novels/poems/short stories & $58 \%$ \\
\hline Writing articles/essays & $13 \%$ \\
\hline Writing book & - \\
\hline Others & $6 \%$ \\
\hline
\end{tabular}

The last question in the first session relates to a topic. It used as a theme in the student's writing. There were $43 \%$ of participants who had written on personal items, and $20 \%$ had brought up the topic of social phenomena in their writing. Furthermore, the choice of answers with political/legal issues was chosen by the participants, around $17 \%$, economic issues 
were selected by $13 \%$ of participants, and $7 \%$ of participants chose other matters.

TABLE 5. THE EXPECTED TOPIC OF DISCUSSION

\begin{tabular}{|c|c|}
\hline \multicolumn{2}{|c|}{$\begin{array}{l}\text { Choose one of the following issues that you have picked } \\
\text { up in your writing! }\end{array}$} \\
\hline Personal topic & $43 \%$ \\
\hline Social phenomenon & $20 \%$ \\
\hline Politics and law & $17 \%$ \\
\hline Economy & $13 \%$ \\
\hline Etc & $7 \%$ \\
\hline
\end{tabular}

\section{B. Students' Language Problem}

In the second part, there are five questions in the questionnaire that are used to identify various problems faced by students in learning writing. The results of identifying these problems are used as considerations and priorities when compiling academic writing textbooks. On the sixth question, the majority of students agreed that writing in academic genres was very difficult $(55 \%)$. Furthermore, participants who answered strongly agreed around $40 \%$ and those who responded neutrally were about $5 \%$.

TABLE 6. ACADEMIC WRITING GENRE IS THE HARDEST GENRE IN WRITING

Understanding language features specific to academic genres is a challenging learning activity

\begin{tabular}{|c|c|}
\hline Strongly agree & $40 \%$ \\
\hline Agree & $55 \%$ \\
\hline Neutral & $5 \%$ \\
\hline Disagree & - \\
\hline Strongly disagree & - \\
\hline
\end{tabular}

Before identifying specific problems, researchers also want to know common problems that are often experienced by students in writing. The seventh question relates to the general problem with the answer of $40 \%$ of participants stating that the difficulty in literature lies in the inadequate mastery of the topics to be written. Other participants chose less knowledge of grammar as the main problem with some of $35 \%$ while the rest chose weak vocabulary mastery as the source of the problem with a total of $25 \%$.

\section{TABLE 7. CONVENTIONAL SOURCES OF PROBLEMS IN WRITING}

In general, the most influential cause of writing learning problems is...

\begin{tabular}{|c|c|}
\hline Weak mastery of vocabulary & $25 \%$ \\
\hline Inadequate knowledge of grammar & $35 \%$ \\
\hline $\begin{array}{c}\text { Insufficient knowledge about the } \\
\text { topics to be written }\end{array}$ & $40 \%$ \\
\hline
\end{tabular}

The questionnaire was also aimed at identifying writing issues more. Specifically, one of which was related to technical factors. As many as $50 \%$ of participants stated that writing a bibliography as a technical problem in writing while $15 \%$ of participants considered the use of punctuation as a technical problem. Furthermore, the factor of timeliness and finding reference sources is the next technical problem with the amount of $25 \%$ and $10 \%$.

\section{TABLE 8. TECHNICAL ASPECTS OF ACADEMIC WRITING}

\begin{tabular}{|c|c|}
\hline \multicolumn{2}{|c|}{$\begin{array}{l}\text { Choose one of the following functional issues, which are } \\
\text { your obstacle to writing! }\end{array}$} \\
\hline Use of punctuation & $15 \%$ \\
\hline Write bibliography/bibliography & $50 \%$ \\
\hline Complete writing on time & $25 \%$ \\
\hline Looking for reference sources & $10 \%$ \\
\hline
\end{tabular}

In some cases, many students have difficulties in writing activities related to writing ideas. The ninth question is submitted to participants to classify this difficulty. There were $40 \%$ of participants stating that the primary challenge was expressing ideas correctly in writing. Furthermore, participants chose the complexity of developing plans and finding ideas as difficulties in writing with a total of $35 \%$ and $25 \%$.

TABEL 9. ASPECTS OF IDEAS IN ACADEMIC WRITING

\begin{tabular}{|c|c|}
\hline \multicolumn{2}{|c|}{ The idea is a separate obstacle in writing, especially in... } \\
\hline Find ideas & $25 \%$ \\
\hline $\begin{array}{c}\text { Develop plans for each paragraph- } \\
\text { express ideas correctly }\end{array}$ & $35 \%$ \\
\hline Find ideas & $40 \%$ \\
\hline
\end{tabular}

The last question in session two is intended to identify aspects of language, which are considered as problems in student writing activities. From this tenth question, it can be concluded that the most challenging issues of communication according to students are: 1) paraphrasing 35\%; 2) making paragraphs effectively and coherently 35\%, and 3) using diction and grammar with precisely $30 \%$.

TABLE 10. LANGUAGE ASPECTS OF WRITING

\begin{tabular}{|c|c|}
\hline \multicolumn{2}{|c|}{$\begin{array}{l}\text { The hardest components in the following aspects of } \\
\text { language are.. }\end{array}$} \\
\hline Paraphrasing & $35 \%$ \\
\hline Write useful and coherent- paragraphs & $35 \%$ \\
\hline Using diction and proper grammar & $30 \%$ \\
\hline
\end{tabular}

\section{Students Language Needs}

Other information that was explored in this study was the needs of students in learning academic writing. This information is used as a benchmark in developing academic writing textbooks in learning Indonesian. There are five questions in this section by asking students' choices related to 
writing learning by integrating elements of the integrative approach in their items.

The eleventh question is related to the type of text students are expected to learn in academic writing learning. There are $50 \%$ of participants who want to write essays and articles in learning to write. Furthermore, participants chose $26.7 \%$ of paragraphs, $16.7 \%$ of writing proposals/theses, $3.3 \%$ of summaries/reviews, and $3.3 \%$ of writing papers.

\section{TABLE 11. TYPES OF TEXT NEEDED IN WRITING LEARNING}

Choose one of the following types of text that you want to prioritize in academic writing learning!

\begin{tabular}{|c|c|}
\hline Paragraph & $26.7 \%$ \\
\hline Essays and articles & $50 \%$ \\
\hline Write a summary/reviewer & $3.3 \%$ \\
\hline Writing papers & $3.3 \%$ \\
\hline Writing research/thesis proposals & $16.7 \%$ \\
\hline
\end{tabular}

In the twelfth question, students are asked to choose answers that are related to the expected assessment in writing learning. From this question, the researcher wants to identify the needs of students about the assessment aspects of academic writing, whether emphasized in linguistic aspects alone or also considering the ideas raised by students in writing. There were $50 \%$ of participants stating that they strongly disagreed with the assessment that only prioritized linguistic aspects, and $33.3 \%$ expressed their disapproval. Other participants chose neutral on this question as much as $10 \%$ and decided to agree as much as 3.3\%. From these results, it can be concluded that the majority of students do not want assessment in writing learning, which is only focused on linguistic aspects and overrides the evaluation of student ideas.

\section{TABLE 12. EVALUATION IN ACADEMIC WRITING}

Assessment of academic writing must be emphasized on the use of correct sentence structure, standard vocabulary, and overruling aspects of original ideas from students!

\begin{tabular}{|c|c|}
\hline Strongly agree & - \\
\hline Agree & $6.7 \%$ \\
\hline Neutral & $10 \%$ \\
\hline Disagree & $33.3 \%$ \\
\hline Strongly disagree & $50 \%$ \\
\hline
\end{tabular}

The thirteenth question is related to aspects that need attention to writing learning. Of the 30 participants, there were 14 people or $46.6 \%$ who chose to develop ideas as aspects that need to be emphasized in writing learning. Another result of this question is that $16.7 \%$ of participants chose vocabulary mastery aspects, $20 \%$ sentence structure aspects, $10 \%$ spelling aspects, and $6.7 \%$ other aspects.

\section{TABLE 13. ASPECTS THAT NEED TO BE PRIORITIZED}

\begin{tabular}{|c|c|}
\hline \multicolumn{2}{|l|}{\begin{tabular}{l} 
In your opinion, the element that must be developed more \\
intensively in writing learning is \\
\hline Sentence structure
\end{tabular}} \\
\hline Develop writing ideas & $40 \%$ \\
\hline Vocabulary Mastery & $16.6 \%$ \\
\hline Spelling & $10 \%$ \\
\hline Other aspects & $6.7 \%$ \\
\hline
\end{tabular}

The next question relates to the need for lecturers to interact continuously in the learning process of writing. Based on the results of the analysis, there were $83.3 \%$ of participants stating that they were firmly committed to providing academic writing activities. The rest of the participants were not much different, $16.7 \%$ said that the guidance in the writing process was essential.

\section{TABLE 14. THE FOR GUIDANCE FOR LECTURERS IN WRITING}

\begin{tabular}{|c|c|}
\hline \multicolumn{2}{|c|}{$\begin{array}{l}\text { Intensive lecturer guidance is needed in learning to write } \\
\text { before writing individually }\end{array}$} \\
\hline Strongly agree & $83.3 \%$ \\
\hline Agree & $16.7 \%$ \\
\hline Neutral & - \\
\hline Disagree & - \\
\hline Strongly disagree & - \\
\hline
\end{tabular}

The fifteenth question is intended to identify the importance of social aspects taught in academic writing activities. In the genre approach, social constructs cannot be released in the context of writing because writing can also be viewed from the viewer's perspective. There are 40\% (24 students) of participants expressing their strong agreement that social aspects need to be also studied in writing learning. Another response from respondents was that $33.3 \% \quad(20$ students) agreed with this, 20\% (12 students) stated neutral, and $6.7 \%$ (4 students) said they did not accept.

\section{TABLE 15. IMPORTANCE OF SOCIAL ASPECTS IN ACADEMIC} WRITING

\begin{tabular}{|c|c|}
\hline \multicolumn{2}{|c|}{$\begin{array}{c}\text { Social elements as part of text construction need to be } \\
\text { studied in writing learning.. }\end{array}$} \\
\hline Strongly agree & $40 \%$ \\
\hline Agree & $33.3 \%$ \\
\hline Neutral & $20 \%$ \\
\hline Disagree & $6.7 \%$ \\
\hline Strongly disagree & - \\
\hline
\end{tabular}

\section{CONCLUSION}

The results of the needs analysis through questionnaires indicate that all students like writing learning. But almost most students are not familiar with writing with 
academic genres. They write more on non-academic or nonscientific writing such as poetry, short stories, diaries through blogs, and so on. Various challenges and obstacles faced by students in writing tend to be evenly distributed, both in linguistic aspects, technical aspects in writing and even in the process of finding and developing written ideas.

Regarding the integrative approach to writing, the majority of students need this approach in learning. This can be seen in the choice of those who want several things: 1) lecturers must play an active role in helping students in writing; 2) the need for social aspects and constructs to be studied before writing activities; and 3) academic writing evaluation aspects of grammar and spelling only but also pay attention to issues of ideas raised in writing.

\section{REFERENCES}

Åberg, E. S., Stahle, Y., Engdahl, I., \& Knutes-Nyqvist, H. (2016). Designing a Website to Support Students' Academic Writing Process. The Turkish Online Journal of Educational Technology, 15(1), 33-42.

Agesta, S., \& Cahyono, B. Y. (2017). Effect of Process-Genre Approach on the Indonesial EFL Writing Achievement Across Personality. International Journal of English Language and Linguistics Research, $5(3), 39-48$.

Amogne, D. (2013). Enhancing Students 'Writing Skills through the Genre Approach. International Journal of English and Literature, 4(5), 242248.

Andi, K., \& Arafah, B. (2017). Using Needs Analysis to Develop English Teaching Materials in Initial Speaking Skills for Indonesian College Students of English. The Turksih Online Journal of Design, Art and Communication, Special Ed(April), 419-436.

Babalola, \& Litinin, H. A. (2012). Effects of Process-genre Based Approach on the Written English Performance of Computer Science Students in a Nigerian Polytechnic. Journal of Education and Practice, 3(6), 1-7.

Badger, R., \& White, G. (2000). A process Genre Approach to Teaching Writing. ELT Journal, 54(2), 153-160.

Bailey, S. (2011). Academic Writing: A Handbook for International Students. New York: Routledge.
Beck, S. W., \& Jeffery, J. V. (2009). Genre and Thinking in Academic Writing Tasks. Journal of Literacy Research, 41(2), 228-272. Brown, J. D. (2001). Using Surveys in Language Programs. Cambridge: Cambridge University Press.

Correa, D., \& Echeverri, S. (2016). Using a Systemic Functional Genre-Based Approach to Promote a Situated View of Academic Writing Among EFL Pre-service Teachers. HOW Journal, 24(1), 44-62.

Eshtehardi, R. (2017). Needs Analysis and Course Design; A Framework for Designing Exam Courses. International Journal of Applied Linguistics \& English $\quad$ Literature, https://doi.org/10.7575/aiac.ijalel.v.6n.6p.274

Ezza, E.-S. Y. (2014). Towards Genre-based Approach to Writing Syllabus in Arab Tertiary Institutions. British Journal of Education, Society \& Behavioural Science, 4(5), 573-580.

Hashemnezhad, H., \& Hashemnezhad, N. (2012). A Comparative Study of Product, Process, and Post-process Approaches in Iranian EFL Students' Writing Skill. Journal of Language Teaching and Research, 3(4), 722-729. https://doi.org/10.4304/jltr.3.4.722-729

Hutchinson, T., \& Waters, A. (1987). English for Spesifik Purpose: A Learning-centered Approach. Cambridge: Cambridge University Press.

Jack C. Richards. (1990). The Language Teaching Matrix. Cambridge: Cambridge University Press.

Lap, T. Q., \& Truc, N. T. (2014). Enhancing Vietnamese Learners' Ability in Writing Argumentative Essays. Journal of Asia TEFL, 11(2), 63-91.

Pasand, P. G., \& Haghi, E. B. (2013). Process-Product Approach to Writing: the Effect of Model Essays on EFL Learners'Writing Accuracy. International Journal of Applied Linguistics \& English Literature, 2(1), 75-79. https://doi.org/10.7575/ijalel.v.2n.1p.75

Pramila, N. (2017). Approaches to Teaching English Writing: A Research Note. Studies in Foreign Language Education, 39, 141-148.

Richards, J. (2011). Curriculum Development in Language teaching. https://doi.org/https://doi.org/10.1017/CBO97 80511667220

Sultana, S. (2018). Need Analysis: An Invaluable Step for Successful Autonomous Learning. English Language Teaching, 11(7), 37-47.

Tangpermpoon, T. (2008). Integrated Approaches to Improve Students Writing Skills for English Major Students. ABAC Journal, 28(2), 1-9.

Tuyen, K. T., Osman, S. Bin, Ahmad, N. S. B., Dan, T. C., \& Kiumarsi, S. (2016). The Effects of Process Genre Approach on Upper Secondary Students' Writing Ability: A Case Study in a Specialized Upper Secondary School in Vietnam. 3(3). 